\title{
Exploring the Impact of Discrimination on the Psychological Well-being of Lesbian Students at South African University Campus
}

\author{
J.G. Kheswa \\ University of Fort Hare, South Africa
}

\begin{abstract}
An exposure to homophobic attacks may vary by a person's place of residency, and at the university, lesbians may function at their optimal level when receiving social and emotional support from the significant others. The aim of this study was to investigate how lesbian students at the University of Fort Hare, South Africa, deal with discrimination. Twenty- one lesbians, aged between 19 and 37 years old, were selected using snowball technique and they gave their informed consent to participate in a qualitative study. Drawing from resilience theory as a theoretical framework of this study, the findings showed that lesbian students experience unconditional positive regard from their lecturers and reported high levels of psychological well-being, namely, self-acceptance, self-autonomy, purpose and meaning in life, positive relationship with others and environmental mastery. In conclusion, this study recommends the implementation of policies on transformation to address diversity at the universities.
\end{abstract}

Keywords: lesbians, discrimination, self-esteem, university, psychological well-being.

\section{Introduction}

Studies conducted at the South African tertiary institutions namely: University of Zululand (Ngcobo, 2007), University of the Western Cape (Mwaba, 2009) and University of Johannesburg (Arndt \& De Bruin, 2006) indicated that the reports on discrimination towards lesbians are caused by students who are homophobic although the American Psychological Association (2008) removed it from the Diagnostic Statistical Manual of Mental Disorders in 1973. In many African societies such as Namibia, Zimbabwe, Nigeria, Zambia and Somalia, homosexuality (i.e sexual relationships with people of the same gender) is condemned, criminalized and viewed as pathology (Francis \& Msibi, 2011), and Kosciw, Greytak, Bartkiewicz, Boesen and Palmer (2012) found that universities pose a hostile environment to a number of lesbians and directly affect the academic achievements, educational aspiration as well as their psychological well-being. Existing research has mostly focused on the perceptions that people and students have towards homosexuals (Ncanana \& Ige, 2014) and none have engaged lesbians in phenomenological study to investigate their experience of discrimination in higher education in the Eastern Cape, South Africa as well as how they enhance their psychological well-being. 
Despite legalization of lesbians' human rights in 1996 in South Africa, attitudes and discrimination against this marginalized group continue to mount. Previous studies found that university students who are devoted to religion demonstrate less favourable views towards lesbians especially the Muslims followed by Orthodox Christians, Catholics and Protestants (Gerhards, 2010; Slenders, Sieben \& Verbakel, 2014) and these homophobic and heterosexual cultural bias may be stressful for lesbians to form romantic relationships with their loved ones owing to religious or cultural identity (Gibson \& MacLeod 2012). Homophobic attitudes entail physical attacks and psychological trauma because they take a form of corrective rape and hate speech (Johnson, Singh \& Gonzalez, 2014). Lesbian is a term that refers to a woman who is emotionally and sexually attracted to other women (Louw \& Louw, 2007), who can be psychologically masculine (high in masculine stereotyped attributes, but low in feminine attributes) and not engaged in sexual relationship with men or be bisexual (i.e having erotic feelings to both men and women) (Tabatabai, 2010).

Globally, Almeida, Johnson, Corlis, Molnar and Azrael (2009), found that when lesbians are subjected to victimization by police and prison guards, the authorities are most likely fail to take reasonable measures to protect them. For example, Almeida et al., (2009) in Brazil, lesbian couple was beaten at a police station and forced to perform oral sex. To show how lesbians are exploited, in Jamaica a lesbian was stabbed to death after the police officer who reportedly participated in the attack, urged others to beat her because of her gender identity. Drawing from feminist theory which is against oppression of women irrespective of their sexual orientation, Worrell and Remer (2002) posited that lesbians must be empowered and protected from patriarchal attitudes in their respective societies. In contrast, an Ugandan pastor Martin Ssempa claimed that lesbianism is not foreign to Africa as same-sex relations existed in Africa long before colonialism (Sexual Minorities Uganda, 2009). Furthermore, Boyd (2013) noted that in precolonial Uganda, lesbians were not killed, persecuted or discriminated.

To date, South African Higher Education (SAHE) has done little if not none to address issues related to homophobia because derogatory names such as inkwili (Francis \& Msibi, 2011) or isitabane (Kheswa, 2014) are still being used to degrade human dignity of lesbians since they are perceived as having polluted sexual culture. Martin-Storey and Crosnoe (2012) maintained that institutions which fail to protect their lesbian students tend to sustain a breeding ground for stigma, discrimination, harassment, emotional abuse as well as physical violence. Stroup, Glass and Cohn (2014) found that discrimination is more prevalent on rural campuses, resulting in forcing lesbians to be invisible, feeling uncomfortable in revealing their sexual orientation. In this way, their socialization is fraught with tension and anxiety due to heterosexist expectations (Zimmerman, 2013). Given the impact of discrimination, Hatzenbuehler (2009) noted that lesbian students may be at greater risk for difficulties with emotional regulation, interpersonal relationships and informed decisions. Not all lesbians who are exposed to anti-gay related discrimination experience the same level of stressors. In comparison, Fingerhut, Peplau and Gable (2010) in their online survey to examine social identity of lesbians, the results showed that lesbians who were outspoken about their sexual orientation reported significantly more discrimination than those who secret about their lesbian identity. Furthermore, Ryan, Russel, Huebner, Diaz and Sanchez (2010) found that lesbians experience immense rejection and verbal harassment and to avoid such threats, violence and degrading treatment from the community, dysfunctional or unsupportive families, they are forced to suppress their homosexual inclinations by being involved in heterosexual relationships. As a result of being vulnerable partly to stigma and violence, lesbians frequently struggle with mental and behavioural concerns such as substance abuse, anxiety, depression, self-harm and suicidal ideation (Ryckman, 2008). 
Nevertheless, research has shown that despite being ridiculed at all levels (e.g. family, peers, church and school) there are lesbians who display psychological hardiness, an integrated sense of the self and resilience (Fassinger \& Arseneau, 2007). An explanation for such minority group's fortitude and ability to flourish stem from the work by Carol Ryff's on eudaimonic well-being (Ryff \& Keyes, 1995). According to her, eudaimonic well-being is about finding meaning, purpose in life and being engaged. No wonder Ncanana and Ige (2014) in their recent investigation of level of aversion towards lesbians at the University of Zululand found heterosexual students showing tolerance and respect. In this study, lesbians were applauded and appreciated for excellence in sports, academics, law, media and entertainment industry. In the same vein, at the University of KwaZulu- Natal, South Africa, Jagessar and Msibi (2015) found that although discrimination is rife at some tertiary institutions, there are some heterosexual students who declare support for LGBT (Lesbians, Gays, Bisexuals and Transgenders) as one of the male students stood up to call for respect towards the rights of every human being regardless of sexual orientation. Against this background, this study seeks to answer the following questions: (i) What are the attitudes conveyed by roommates, peers and lecturers towards lesbians? and (ii) How do lesbian students enhance their psychological well-being against discrimination?

\section{Theoretical Framework}

This study is underpinned by resilience theory. Resilience has been conceptualized as the ability to positively navigate through adverse circumstances and involving emotional intelligence and self-regulation to adapt and buffer against negative outcomes associated with risk exposure (Craig, McInroy, McCready \& Alaggia, 2015). Several components that have been found to facilitate resilience among lesbians are emotional and social support, self-esteem and selfcompetence to attain self-actualization and experience optimal mental health (Mustanski, Newcomb \& Gorafalo, 2011). Resilience theory is consistent with ecological theoretical approach (Bronfenbrenner, 1979) and Ryff's model of psychological well-being. Social-ecological model views social factors (i.e. interpersonal relationship with lecturers, family members and church) and structural factors (livelihood circumstances) as inextricably linked (Craig et al., 2015).

\section{Method}

\subsection{Design}

The research design of this study was qualitative and of exploratory, descriptive, and contextual nature. The study employed a phenomenological approach since the researcher was concerned about how discrimination impacts on the psychological well-being of lesbian students at university campus, and to discover how the make sense of what happens in their lives. An open ended structured questionnaire to gain insight into how lesbian students cope with discrimination satisfied the exploratory nature of the research. The researcher thoroughly described the respondents' experiences within the context of the university located in a rural setting, using axial, selective and open coding. The primary research question of this study was: How does discrimination impact on the psychological well-being of lesbian students at university campus?

\subsection{Sample and Sampling}


The sample for this study comprised 21 black lesbian students between ages 18 and 37 years studying at the University of Fort Hare (Alice Campus) situated in Alice location, Nkonkobe Municipality, Eastern Cape Province, South Africa. Probability sampling was applied using a snowball technique since the respondents were not conveniently available. The twenty one participants were from various villages in the province and spoke IsiXhosa although they filled the questionnaires in English.

\section{Trustworthiness}

To establish trustworthiness of the research study, four alternative constructs by Lincoln and Guba (1985) also cited in Krefting (1991) were adopted, namely; credibility, dependability, confirmability and transferability. To ensure credibility, all the participants were taken through the same questions and interviewed to the point at which there was data saturation (prolonged engagement). Dependability was achieved through a dense description of the research methodology employed to conduct the study and data which was organised into themes after the verbatim transcriptions and translations, findings and the recommendations have been made. Confirmability was ensured by audit trial of the verbatim descriptions and themes (Krefting, 1991). The researcher followed the probability sampling, described the research context and participants' background to enable anyone interested in making a transfer, to reach a conclusion about whether transfer could be possible or not (de Vos, Strydom, Fouche, \& Delport, 2011). Transferability was ensured by a literature control after data collection where similar finding of previous research studies were reported.

\section{Ethical considerations}

To safeguard the human dignity of the participants, it was necessary to adhere to the ethical principles. The participants were asked to give their informed consent and they were assured of their right to confidentiality, privacy and anonymity as suggested by Babbie (2010). Anonymity was maintained by giving numbers to participants as a form of identification during the interview and the transcriptions were validated after the researcher referred back to a few participants to validate the transcriptions. It is important to note that this study took place in October 2014 in the Psychology Department following the endorsement by the Ethical Committee and the Dean of Students. Confidentiality was ensured by destroying the audio-tapes after the completion of the research.

\section{Results}

\subsection{Social support}

The first theme relates to family and siblings' support. When asked to explain any support that they receive from their families. Their responses confirmed that they get all the emotional and psychological support they need from their parents, sisters and extended families. Their responses are as follows:

"I come from a very loving and supportive family hence I have reached this level of success.

Family is my source of strength and I am surrounded by loving friend, comrades and colleagues" (Aged, 25).

"The support system from my family and peers is the greatest"(Age 30 
"I receive support from my sister, she is very supportive, she understands me and she likes what I am doing and my mom, but then she does not show it but I can see that she support me" ( Age 19)

"I have good support from my family" (Age 37)

\subsection{Alienation}

Another theme that emerged from the respondents was related to alienation. Most of the respondents expressed lack of sense of belonging and withdrawal from roommates as result of stigmatization. Feelings of emotional detachment were common among the respondents as they experienced alienation from church and even when they share bathrooms at the university hostels. For example, they mentioned:

"The community and churches perceive me as demon" (Age 23)

"The church doesn't accept me and sometimes Pastors make sarcastic remarks when preaching as a result I don't go to church anymore." (Age 20)

"At first they did not want to bath or undress in front of me because they were afraid of me assuming that I will sexual harass them." (Age 25)

The researcher found out that the participants are hopeless in terms of family reintegration and they are the ones who lived with the guilt concerning their identity. However one participant revealed that:

"We have good support from our peers and family who respect our choices" (Age 29).

\subsection{Attitude from lecturers}

According to the respondents, much of emotional support is derived from their lecturers' positive attitudes and they highlighted that because of conducive environment during lectures, their human relations with other students have improved significantly.

"I have never come across challenges with my lecturers regarding my sexuality" (Aged 21).

Lecturers treat us all equally; I have not had any bad experience "(Age 22).

"I did not encounter any in the past three years. And when they address theories which are anti-gay, they remind us of the Constitution of South Africa and emphasized that no one has the right to discriminated against homosexuals "(Age 24).

"To be honest here in varsity have not come any difficulties, lecturers are understandable and flexible" (Age 25)

\subsection{Non-violent environment}

The narratives cited below indicate that lesbians are not victims of hate- crimes as most of them mentioned that they have never heard of any lesbians that has been killed or rape and the university is safe from homophobic attacks.

"I have never had of any case of lesbian raped in these years that I studied here. I have not experienced nor heard of any story relating to that" (Age 24)

"Even during social events, we are free like other students and very often we meet at the church, student meetings and sport grounds while Rugby plays, no matter how late it may be "(Age 26) 
"Fortunately, Fort Hare is a very friendly campus and environment so everything has been great so far, it's so amazing how understanding and problem free the student are" (Age, 32),

\subsection{Psychological Well-being}

There was a strong affirmation among the respondents that they do not feel different from nonheterosexual women. For example, two respondents were clear in their views: "I am proud of who I am because I won't change it and no one can. I love myself and respect myself"(Aged 28). "I feel ok I guess. I didn't choose to be like this and I cannot fight being like this. I love myself and I love what I am" (Aged 22).

Furthermore, their responses indicated that lesbian students experience intimacy and secure attachment. In the following statements: "We just understand and love each other like any other heterosexual couple of course there are challenges but we cope"(Age 19)" It is to be faithful to your partner and workout any challenges that we face as a couple"(Age 21), "I keep my relationship by keeping my woman happy by loving her and make sure she laughs and feel loved and I believe that communication is the key to every relationship"(Age 29). Furthermore, the respondents highlighted they experience high level of mental health and low level of mental illness because they do not drink alcohol nor use drugs as they were cited as follows:

"To be respected by the Fort Hare community I do not need to be popular and lower my dignity by drinking alcohol" (Age 26).

"I found meaning and purpose in playing Rugby than to drink alcohol. Right now, I represent the national team because I am disciplined" (Age 23)

\section{Discussion}

Although social support promotes resilience and self- acceptance, some form of discrimination from the pastors and roommates has been reported to have deleterious impact on the psychological well-being of lesbians because they stopped attending church when they are at home. However, in this study, lesbian students reported higher perceived social support which was strongly linked to lower depression, greater life-satisfaction and high esteem. This finding corresponds with what Needham and Austin (2010) found among college students in the United States of America. In the quantitative study among gays and lesbians, more than $65 \%$ showed emotional stability and academic excellence as a result of parental support and nurturance. It is clear that although some of the lecturers at the University of Fort Hare are from countries such as Nigeria and Zimbabwe (which do not tolerate homosexuality), they respect the sexual orientation of the students and support the students academically and morally. This is consistent with Alexander Astin's involvement theory (1999) which posits that the academic performance of any student on campus is likely to improve when the lecturers are friendly, cooperative and characterized by unconditional positive regard. Furthermore, they confidently mentioned that the university atmosphere is conducive to learning and the students are very welcoming and tolerant as they have never heard of cases pertaining to corrective rape and hate crime. This is in contrast with the South African studies conducted by Nel and Judge (2008) at one of the universities in Johannesburg that lesbians are at high risk of corrective rape and hate crimes and Harrison and John (2012) who found that a lesbian student at Stellenbosch University reported physical and verbal abuse from male students at the hostel. In the Eastern Cape, tolerance of lesbianism could be attributable to cultural practices that I observed even during the lectures and social gatherings in the villages because majority of the male students are predominantly Xhosa- 
speaking and have traditionally circumcised. This finding is in line with the societal expectations that men should show respect to women, strive for peace and to be providers of their households (Kheswa, Nomgcoyiya, Adonis \& Ngeleka, 2014). Also, this study concurs with the general argument that education fosters liberal attitudes as suggested by Slenders et al., (2014) because in countries such as Australia and United States, university students have tolerance and positive attitude towards gays and lesbians (Kwok, Wu \& Shardlow, 2014). Speculations could be that this group of lesbian students is more likely to be preoccupied with activities which harness their psychological well-being as compared to low level of self- regulation and experience low academic performance and maladaptiveness. According to Burke (2012), self- regulation is a systematic process of human behaviour which involves setting of personal goals gearing toward attainment of established goals.

This study also found that the experience of secure attachment by lesbians with significant others contributes increasing their sense of autonomy and self-acceptance. The participants fully expressed that they find satisfaction from their sexual partners and they build mutual trust with them to gain sense of belonging, boost their self- esteem and regaining their source of strength and happiness. On the contrary, Swank, Fahs and Frost, (2013) found that lesbians who have accepted their sexual identity and come out of the closet, were reported to be more likely to experience verbal harassment and physical attacks than those who reported less disclosure. The above suggests that to improve the well- being of students irrespective of one's sexual orientation, an adoption of Abraham Maslow's motivation theory which posits some reinforcements in relation to deficiency needs (e.g. sense of belonging) is important (Weiten, 2011).

Borrowing from PERMA Model by Martin Seligman (2011) from Positive Psychology and from Seligman's statement that "the construct of well-being ....... is the focal topic of positive psychology" (2011: 15). The acronym 'PERMA' stands for five essential elements of well-being theory, that is, Positive emotion, Engagement; Relationships; Meaning and Accomplishment (Compton \& Hoffman, 2013; Seligman, 2011). In this regard, majority of respondents expressed that they are safe from sexual harassment and in most cases they engage in sports and student movements promoting their spiritual well-being. Finally, owing to self-regulation and internal locus of control, they do not indulge in alcohol and drug abuse.

\section{Conclusion}

In conclusion, this research study sought to highlight the experience of lesbians residing in student accommodation space at one of the South African university campuses. Although some new findings emerged from this qualitative study, the limitations are that the sample might not be a true representative of the lesbians at the universities based in other provinces since they were black IsiXhosa- speaking who are not drinking alcohol. The findings demonstrated that although the university is in rural areas, heteronormative practices still exist and therefore transformation in institutions of higher learning must be advocated for the achievement of tolerance and respect for human dignity. Universities have to be more proactive, implement inclusive policies and training for all stakeholders to ensure that diversity in all manifestation is fully comprehended.

\section{Acknowledgement}

This study was financially supported by the Govan Mbeki Research and Development Centre from the University of Fort Hare, South Africa. 


\section{References}

Almeida, J., Johnson, R. M., Corliss, H. L., Molnar, B. E., \& Azrael, D. (2009). Emotional distress among LGBT youth: The influence of perceived discrimination based on sexual orientation. Journal of youth and adolescence, 38(7), 1001-1014.

American Psychological Association (2008). Answer to your questions for a better understanding of sexual orientation $\mathcal{E}$ homosexuality. Retrieved from http://www.apa.org/topics/sexuality/sorientation.pdf

Arndt, M., \& De Bruin, G. (2006). 'Attitudes toward lesbians and gay men: Relations with gender, race and religion among university students'. Psychology in Society, 33, 16-30.

Astin, A. (1999). Student involvement: A developmental theory for higher education. Journal of College Student Development, 40(5), 518-529.

Babbie, E. (2010). The practice of social research. (12 ${ }^{\text {th }}$ ed). Wadsworth: Belmont USA.

Boyd, L. (2013). The problem with freedom: Homosexuality and human rights in Uganda. Anthropological Quarterly, 86(3), 697-724.

Bronfenbrenner, U. (1979). The ecology of human development. Harvard University Press, Cambridge, Massachusetts, USA.

Burt, A. (Ed.) (2012). Abnormal Psychology. A South African perspective. $\left(2^{\text {nd }}\right.$ ed.). Cape Town: Oxford University Press.

Cohn, T. J., \& Hastings, S. L. (2010). Resilience among rural lesbian youth. Journal of Lesbian Studies, 14(1), 71-79. doi:10.1080/10894160903060325

Compton, W. C., \& Hoffman, E. (2013). Positive psychology: The science of happiness and flourishing. Belmont, CA: Wadsworth.

Craig, S. L., McInroy, L., McCready, L. T., \& Alaggia, R. (2015). Media: A Catalyst for Resilience in Lesbian, Gay, Bisexual, Transgender, and Queer Youth. Journal of LGBT Youth, 12(3), 254-275.

de Vos, A. S., Strydom, H., Fouche, C.D, \& Delport, C.S.L (2011). Research at Grass Roots: For the social sciences and human services professions. (4 ${ }^{\text {th }}$ ed.) Van Schaik Publishers: Pretoria.

Fassinger, R. E., \& Arseneau, J. R. (2007). " I'd Rather Get Wet Than Be Under That Umbrella": Differentiating the Experiences and Identities of Lesbian, Gay, Bisexual, and Transgender People. In K. J. Bieschke, Perez, R. M., \& DeBord, K. A. (Eds.), Handbook of counseling and psychotherapy with lesbian, gay, bisexual, and transgender clients (2nd ed., pp. 19-49). Washington, DC: American Psychological Association.

Fingerhut, A. W., Peplau, L. A., \& Gable, S. L. (2010). Identity, minority stress and psychological well-being among gay men and lesbians. Psychology \& Sexuality, 1(2), 101-114.

Francis, D., \& Msibi, T. (2011). Teaching about heterosexism: Challenging homophobia in South Africa. Journal of LGBT Youth, 8(2), 157-173.

Gerhards, J. (2010). Non-discrimination towards homosexuality: The European Union's policy and citizens' attitudes towards homosexuality in 27 European countries. International Sociology, 25(1): 5-28.

Harrison, D., \& John, V. (2012, March 23) 'Stellenbosch faces up to discrimination', in Mail and Guardian, available at: http://mg.co.za/article/2012-03-23-stellenbosch-faces-up-to-discrimination

Hatzenbuehler, M. L. (2009). How does sexual minority stigma 'get under the skin'? A psychological mediation framework. Psychological Bulletin, 135, 707-730.

Jagessar , V., \& Msibi, T. (2015) "It's not that bad": Homophobia in the residences of a university in KwaZulu-Natal, Durban, South Africa, Agenda, 29:1, 63-73.

Johnson, C. W., Singh, A. A., \& Gonzalez, M. (2014). "It's complicated": Collective memories of transgender, queer, and questioning youth in high school. Journal of homosexuality, 61(3), 419-434.

Kheswa, J.G. (2014). Exploring the causal factors and the effects of sexual harassment on female students at the universities in Africa. An overview. Mediterranean Journal of Social Sciences, Vol 5, (17),

Kheswa, J. G., Nomngcoyiya, T., Adonis, P., \& Ngeleka, S. (2014). The Experiences and Perceptions of "amakrwala"(Graduated Initiates) towards the Traditional Male Circumcision Practice in Eastern Cape, South Africa. Mediterranean Journal of Social Sciences, 5(20), 2789-.

Kosciw, J. G., Greytak, E. A., Bartkiewicz, M. J., Boesen, M. J., \& Palmer, N. A. (2012). The 2011 national school climate survey: The experiences of lesbian, gay, bisexual and transgender youth in our nation's schools. New York, NY: GLSEN. 
Krefting, L. (1991). Rigor in qualitative research: The assessment of trustworthiness. American journal of occupational therapy, 45(3), 214-222.

Kwok, D. K., Wu, J., \& Shardlow, S. M. (2013). Attitudes Toward Lesbians and Gay Men Among Hong Kong Chinese Social Work Students. Journal of Social Work Education, 49(2), 337-352.

Lincoln, Y.S., \& Guba, E.G. (1985). Naturalistic inquiry. Newbury Park, CA: Sage.

Johnson, B. (2014). The need to prepare future teachers to understand and combat homophobia in schools. South African Journal of Higher Education, 28(4), 1249- 1268.

Louw, D. \& Louw, A. (2007). Child and adolescent development. The University of Free State: Bloemfontein.

Martin-Storey, A., \& Crosnoe, R. (2012). Sexual minority status, peer harassment, and adolescent depression. Journal of Adolescence, 35, 1001-1011.

Mustanski, B., Newcomb, M. E., \& Garofalo, R. (2011). Mental health of lesbian, gay, and bisexual youths: A developmental resiliency perspective. Journal of Gay and Lesbian Social Services, 23, 204-225.

Mwaba, K. (2009). Attitudes and beliefs about homosexuality and same-sex marriage among a sample of South African students. Social Behavior and Personality: an international journal, 37(6), 801-804.

Ncanana, Z., \& Ige, K. D. (2014). Aversion toward Homosexuals among Tertiary Education Students in South Africa. Mediterranean Journal of Social Sciences, 5(10), 569-579.

Nel, J. A., \& Judge, M. (2008). Exploring homophobic victimisation in Gauteng, South Africa: Issues, impacts and responses. Acta Criminologica, 21, 19-36.

Needham, B. L., \& Austin, E. L. (2010). Sexual orientation, parental support, and health during the transition to young adulthood. Journal of Youth and Adolescence, 39, 1189-1198. doi:10.1007/s10964-010-9533-6

Ngcobo, N.P. (2007). 'Difficulties faced by homosexual students at the University of Zululand: A phenomenological study', Master's thesis, University of Zululand, KwaDlangweza.

Ryan, C., Russell, S. T., Huebner, D., Diaz, R., \& Sanchez, J. (2010). Family acceptance in adolescence and the health of LGBT young adults. Journal of Child and Adolescent Psychiatric Nursing, 23(4), 205-213.

Ryckman, R. M. (2008). Theories of personality: International student edition. ( $9^{\text {th }}$ ed.). United State of America: Thomson Wadsworth.

Ryff, C. D., \& Keyes, C. L. M. (1995). The structure of psychological well-being revisited. Journal of personality and social psychology, 69(4), 719.

Seligman, M. E. (2011). Learned optimism: How to change your mind and your life. Random House LLC.

Sexual Minorities Uganda (SMUG). (2009). Condemn the tabled Anti- Homosexuality Bill. Statement, October 15. Sexual Minorities Uganda.

http://www.iglhrc.org/cgi-bin/iowa/article/takeaction/partners/988.html.

Slenders, S., Sieben, I., \& Verbakel, E. (2014). Tolerance towards homosexuality in Europe: Population composition, economic affluence, religiosity, same-sex union legislation and HIV rates as explanations for country differences. International Sociology, 29(4), 348-367.

Stroup, J., Glass, J., \& Cohn, T. J. (2014). The adjustment to US rural college campuses for bisexual students in comparison to gay and lesbian students: an exploratory study. Journal of Bisexuality, 14(1), 94-109.

Swank, E., Fahs, B., \& Frost, D. M. (2013). Region, social identities, and disclosure practices as predictors of heterosexist discrimination against sexual minorities in the United States. Sociological Inquiry, 83(2), $238-258$

Tabatabai, A. (2010). Protecting the lesbian border: The tension between individual and communal authenticity. Sexualities, 13(5), 563-581.

Weiten, W. (2011). Psychology themes \& variations (8th ed.). Las Vegas, NV: University of Nevada.

Worell, J., \& Remer, P. (2002). Feminist perspectives in therapy: Empowering diverse women. John Wiley \& Sons.

Zimmerman, B. (Ed.). (2013). Encyclopedia of Lesbian histories and cultures. Routledge.

J.G. Kheswa is Senior Lecturer, Department of Psychology, University of Fort Hare, Private Bag X1314, Alice, 5700, South Africa. 